\title{
Commentary: Intermittent Hypoxia Severity in Animal Models of Sleep Apnea
}

\author{
Jonathan C. Jun ${ }^{1 *}$ and Erik R. Swenson ${ }^{2}$ \\ ${ }^{1}$ Pulmonary and Critical Care Medicine, School of Medicine, Johns Hopkins University, Baltimore, MD, United States, \\ ${ }^{2}$ Pulmonary and Critical Care Medicine, University of Washington, Seattle, WA, United States
}

Keywords: hypoxia, hemoglobin, dissociation, sleep apnea, altitude

\section{A Commentary on}

Intermittent Hypoxia Severity in Animal Models of Sleep Apnea

by Farre, R., Montserrat, J. M., Gozal, D., Almendros, I., and Navajas, D. (2018). Front. Physiol. 9:1556. doi: 10.3389/fphys.2018.01556

OPEN ACCESS

Edited by:

Yu Ru Kou,

National Yang-Ming University, Taiwan

Reviewed by:

Andrew E. Beaudin,

University of Calgary, Canada

*Correspondence: Jonathan C. Jun

jjun2@Jhmi.edu

Specialty section: This article was submitted to Respiratory Physiology, a section of the journal Frontiers in Physiology

Received: 01 April 2019 Accepted: 29 April 2019 Published: 22 May 2019

Citation: Jun JC and Swenson ER (2019) Commentary: Intermittent Hypoxia

Severity in Animal Models of Sleep Apnea. Front. Physiol. 10:609. doi: 10.3389/fphys.2019.00609
Obstructive sleep apnea (OSA) is a common disorder that leads to problems including intermittent hypoxia ( $\mathrm{IH})$ and arousals from sleep. To simulate consequences of OSA, some studies expose rodents to $\mathrm{IH}$ with the intention of simulating the oxygen profile experienced by OSA patients. Some IH experiments induce hemoglobin oxygen saturation $\left(\mathrm{SaO}_{2}\right)$ to fall to $50-70 \%$ during the nadir phase. In a recent review, we stated that this degree of hypoxemia is more severe than that experienced by typical OSA patients (Chopra et al., 2015). Farre et al. challenged this statement (Farré et al., 2018), pointing out that small mammals such as rodents have a right-shifted oxyhemoglobin dissociation curve (ODC) compared to humans (Schmidt-Nielsen, 1970). They argue that the higher arterial partial oxygen pressure $\left(\mathrm{PaO}_{2}\right)$ for a given $\mathrm{SaO}_{2}$ confers mice with "better oxygen reserve." To achieve $\mathrm{PaO}_{2}$ nadir values similar to those experienced by severe OSA patients they contend, " $\mathrm{SaO}_{2}$ in mice should be much lower than the $\mathrm{SaO}_{2}$ observed in patients." We disagree with this statement, which relies on $\mathrm{PaO}_{2}$ as an indicator of tissue oxygenation. Arterial $\mathrm{O}_{2}$ content $\left(\mathrm{CaO}_{2}\right)$ is determined by classic formula:

$$
\mathrm{CaO}_{2}=\left(1.34 \times \mathrm{Hb} \times \mathrm{SaO}_{2}\right)+\left(0.003 \times \mathrm{PaO}_{2}\right)
$$

Systemic $\mathrm{O}_{2}$ delivery $\left(\mathrm{DO}_{2}\right)$ is the product of blood flow $(\mathrm{Q})$ and $\mathrm{CaO}_{2}$. From these equations, it is apparent that $\mathrm{PaO}_{2}$ as it determines the amount of dissolved $\mathrm{O}_{2}$ gas, itself has a negligible contribution to $\mathrm{CaO}_{2}$ or $\mathrm{DO}_{2}$. As oxygenated blood reaches target tissues, $\mathrm{O}_{2}$ dissociates from hemoglobin to maintain a favorable capillary-to-tissue $\mathrm{PO}_{2}$ driving gradient. When $\mathrm{O}_{2}$ diffuses into tissues, systemic capillary $\mathrm{PaO}_{2}$ falls, and is replenished by upstream oxygenated hemoglobin. Aerobic metabolic processes then consume cell $\mathrm{O}_{2}$. The balance between $\mathrm{O}_{2}$ supply and demand determines the cellular $\mathrm{PO}_{2}$. Therefore, cellular $\mathrm{PO}_{2}$-the parameter that truly determines oxygen adequacy - depends upon $\mathrm{DO}_{2}$, capillary density, and rates of $\mathrm{O}_{2}$ utilization. A right-shifted ODC means that $\mathrm{O}_{2}$ is unloaded from hemoglobin more rapidly, but this does not increase the total amount of $\mathrm{O}_{2}$ delivered. 
To propose that mice should have their $\mathrm{SaO}_{2}$ lowered in order to achieve a $\mathrm{PaO}_{2}$ equal to that of humans is tantamount to suggesting that one should load a truck to only half its capacity, because it unloads boxes twice as quickly. If we invoke this logic, and use the figure provided by Farre et al., mouse $\mathrm{SaO}_{2}$ would have to be decreased to $\sim 75 \%$ to match a normoxic human $\mathrm{PaO}_{2}$ at $\sim 65 \mathrm{~mm} \mathrm{Hg}$. Mice exposed to hypoxemia of this magnitude exhibit robust erythrocytosis (Fagan, 2001) and activate anaerobic metabolic pathways (Jun et al., 2012, 2014) indicating that mice are effectively hypoxic at a higher $\mathrm{PaO}_{2}$ than humans. Their higher $\mathrm{PaO}_{2}$ may be necessary to maintain adequate tissue $\mathrm{PO}_{2}$ (as opposed to having "better oxygen reserve"), as mice have dramatically higher mass-specific metabolic rates than humans. Therefore, we should be targeting equivalent drops in $\mathrm{SaO}_{2}$ between humans and rodents if the goal is to reduce distal $\mathrm{O}_{2}$ delivery to the same extent.

Implicit in the argument by Farre et al. is that a right-shifted ODC is advantageous in mitigating effects of low $\mathrm{SaO}_{2}$. There is no evidence that we could find to support this argument. A right-shifted ODC is advantageous in states such as shock or hemorrhage ensuring $\mathrm{O}_{2}$ is maximally transferred to ischemic tissues (Agostoni et al., 1975; da Luz et al., 1975; Cornum et al., 1998; Morgan, 1999). Conversely, transfusion of blood depleted of 2,3 diphosphoglycerate to left-shift the ODC (Riggs et al., 1973) decreases tissue oxygen supply. These examples pertain to conditions when hemoglobin is fully $\mathrm{O}_{2}$ saturated (i.e., $\mathrm{SaO}_{2}$ is constant). What is the effect of shifting the ODC during hypoxemia (e.g., high altitude, OSA)? Here, effects of hemoglobin $\mathrm{O}_{2}$ affinity are not straightforward. Left shifting

\section{REFERENCES}

Agostoni, A., Lotto, A., Stabilini, R., Bernasconi, C., Gerli, G., Gattinoni, L., et al. (1975). Hemoglobin oxygen affinty in patients with low-output heart failure and cardiogenic shock after acute myocardial infaraction. Eur. J. Cardiol. 3, 53-58.

Chopra, S., Polotsky, V. Y., and Jun, J. C. (2015). sleep apnea research in animals: past, present, and future. Am. J. Respir. Cell Mol. Biol. 54, 299-305. doi: 10.1165/rcmb.2015-0218TR

Cornum, R. L., Martin, R. R., and Bandy, W. C. (1998). Transfusion of phosphoenolpyruvate-treated blood increases oxygen consumption in acute hemorrhage. Am. J. Surg. 175, 469-471.

da Luz, P. L., Cavanilles, J. M., Michaels, S., Weil, M. H., and Shubin, H. (1975). Oxygen delivery, anoxic metabolism and hemoglobin-oxygen affinity (P50) in patients with acute myocardial infarction and shock. Am. J. Cardiol. 36, 148-154

Eaton, J. W., Skelton, T. D., and Berger, E. (1974). Survival at extreme altitude: protective effect of increased hemoglobin-oxygen affinity. Science 183, 743-744.

Fagan, K. A. (2001). Selected contribution: pulmonary hypertension in mice following intermittent hypoxia. J. Appl. Physiol. 90, 2502-2507. doi: 10.1152/jappl.2001.90.6.2502

Farré, R., Montserrat, J. M., Gozal, D., Almendros, I., and Navajas, D. (2018). Intermittent hypoxia severity in animal models of sleep apnea. Front. Physiol. 9:1556. doi: 10.3389/fphys.2018.01556

Jun, J. C., Shin, M. K., Devera, R., Yao, Q., Mesarwi, O., Bevans-Fonti, S., et al. (2014). Intermittent hypoxia-induced glucose intolerance is abolished by alpha- the ODC increases $\mathrm{O}_{2}$ uptake in the pulmonary capillaries, but compromises peripheral tissue $\mathrm{O}_{2}$ unloading. At high altitude, this trade-off is advantageous for survival; the "tipping point" occurs when $\mathrm{O}_{2}$ uptake becomes diffusion limited (Storz and Moriyama, 2008). Indeed, rats exposed to severe hypoxia survived longer with a left-shifted ODC (Eaton et al., 1974). The rightward ODC curve of rodents may actually be counterproductive in the setting of ambient hypoxia.

In conclusion, we should not "titrate" $\mathrm{SaO}_{2}$ in different species to match their $\mathrm{PaO}_{2}$, based on different hemoglobin $\mathrm{O}_{2}$ affinities. We stand by our statement that $\mathrm{IH}$ experiments that lower the $\mathrm{SaO}_{2}$ of mice to nadirs of $50-70 \%$ are severe. Our intent was not to dismiss the importance or validity of these IH models. We merely object to the claim that $\mathrm{SaO}_{2}$ needs to be lowered more in mice than humans to simulate consequences of OSA.

\section{AUTHOR CONTRIBUTIONS}

JJ and ES collaboratively wrote the manuscript.

\section{FUNDING}

This manuscript was supported by NIH R01HL135483 and R03HL138068.

\section{ACKNOWLEDGMENTS}

Authors would like to thank Dr. Jerome Dempsey and Dr. Norberto Gonzalez who participated in discussions on this topic.

adrenergic blockade or adrenal medullectomy. Am. J. Physiol. Endocrinol. Metab. 307, E1073-E1083. doi: 10.1152/ajpendo.00373.2014

Jun, J. C., Shin, M. K., Yao, Q., Bevans-Fonti, S., Poole, J., Drager, L. F., et al. (2012). Acute hypoxia induces hypertriglyceridemia by decreasing plasma triglyceride clearance in mice. Am. J. Physiol. Endocrinol. Metab. 303, E377E388. doi: 10.1152/ajpendo.00641.2011

Morgan, T. J. (1999). The oxyhaemoglobin dissociation curve in critical illness. Crit. Care Resuscitat. 1, 93-100.

Riggs, T. E., Shafer, A. W., and Guenter, C. A. (1973). Acute changes in oxyhemoglobin affinity. Effects on oxygen transport and utilization. J. Clin. Investig. 52, 2660-2663.

Schmidt-Nielsen, K. (1970). Energy metabolism, body size, and problems of scaling. Fed. Proc. 29, 1524-1532.

Storz, J. F., and Moriyama, H. (2008). Mechanisms of hemoglobin adaptation to high altitude hypoxia. High Alt. Med. Biol. 9, 148-157. doi: 10.1089/ham.2007.1079

Conflict of Interest Statement: The authors declare that the research was conducted in the absence of any commercial or financial relationships that could be construed as a potential conflict of interest.

Copyright (c) 2019 Jun and Swenson. This is an open-access article distributed under the terms of the Creative Commons Attribution License (CC BY). The use, distribution or reproduction in other forums is permitted, provided the original author(s) and the copyright owner(s) are credited and that the original publication in this journal is cited, in accordance with accepted academic practice. No use, distribution or reproduction is permitted which does not comply with these terms. 